\title{
Does the Socialization of Young Russian Academics Foster Migration?
}

\author{
Andreas Siegert \\ International University of Corporate Education IBA, Erfurt \\ siegertandreas@web.de
}

\begin{abstract}
Many Russian scientists left their country when the Soviet Union collapsed, as migration to them meant an option to improve living standard and professional career. Which socio-demographic attributes describe young Russian academics today who want to study or conduct research abroad? Which values or attitudes are of importance to them? On base of two representative questionnaires, sociodemographical characteristics, motivations to migrate, as well as countries of destinations were evaluated among 500 Russian academics, who had studied or conducted research in Germany. The results of those interviews permitted to distinguish types of migrants, deliver new insights into the processes of migration and explain why highly qualified Russians migrate. The study shows correlations between socialisation of interviewees and its impact on future decisions to migrate.
\end{abstract}

Key words: Migration, Russian academics, brain-exchange, global scientific community,

The following article focuses on the migration of young Russian academics (younger then 25 years and thus born in the 1980s), their socio-demographic background and values, and the social or professional groups to which they assign themselves. The article points out which age group prefers contacts with Diaspora and which prefers contact with professional communities. Essentially, the article aims to address Stichweh's question: "How scientific knowledge globalises?". ${ }^{1}$

\section{State of the Art}

Since World War Two, migration movements have expanded. ${ }^{2}$ Parallel to this, previous explanations and definitions of migration have become increasingly differentiated. ${ }^{3}$ For the purpose of this article, Han's definition of migration has been applied as "permanent

\footnotetext{
1 R. Stichweh, Globalisierung von Wirtschaft und Wissenschaft, Produktion und Transfer wissenschaftlichen Wissens in zwei Funktionssystemen der modernen Gesellschaft, <http:/ / www.unibielefeld.de/ (de)/ soz/ iw/ projekte/ projekteabgeschlossen.html>, accessed on April 23, 2007, p. 3.

2 P. Han, Soziologie der Migration, Stuttgart, UTB Vol. 2118, 2005, p. 1.

3 A. Treibel, Migration in modernen Gesellschaften, 3'd edition; München/ Weinheim, J uventa Verlag 2003 , p 7.
} 
or temporary geographical and social movement and structural attribute of the global labour." 4

The collapse of the Soviet Union meant an additional impulse to world-wide migration. Many highly qualified Soviet scientists took the chance and accepted job offers abroad. But how did those structural attributes of the global labour market that Han mentions come about?

There has already been research on the connection between studying abroad and a readiness to migrate. The results showed that international elite of highly qualified is emerging and being fostered by their migration. ${ }^{5}$ Studying abroad was often shown to be part of career plans. Surveys of Gochberg ${ }^{6}$ and research on the migration of Russian transmigrants confirm those findings within the particular context of Russian academics leaving for Germany, too. ${ }^{7}$

Nevertheless, according to J ahr et al., 8 there has been relatively little scientific study of international mobile individuals to date. The design of research that has been conducted is predominantly qualitative or based on examples. ${ }^{9}$ However, quantitative research is required to gain a deeper understanding of migration and the situation of those concerned. ${ }^{10}$ Finally, quantitative surveys are necessary to determine the significance and universal validity of qualitative results. This article seeks to address the deficit. It uses various methods, namely secondary analysis of previous interviews (carried out by Gochberg), interviews with experts, as well as standardised interviews and one-to-oneinterviews with migrants.

Twenty years after the fall of the Berlin Wall, the following aspects are examined: (1) What is the extent and complexity of migration of Russian highly skilled individuals?; (2) Which attributes characterise young Russian academics studying or conducting research in Germany?; (3) According to which criteria do the young Russian academics decide on possible countries of destination?; and (4) As members of the "Global Scientific Community", do they prefer private or professional networks to find social orientation?

These questions are answered on the basis of an empirical research. The article furthermore outlines possible theories to explain the migration of young Russian academics.

\footnotetext{
${ }^{4}$ P. Han, op.cit., p. 9.

${ }^{5}$ J . Salt, International Movements of the Highly Skilled, Occasional Papers, Paris, OECD, 1997, p. 23.

${ }^{6}$ L. M. Gochberg, Vosproizvodstvo naučnoj èlity $v$ Rossii. Rol' zarubežnych naučnych fondov. Moscow, Frantera, 2005.

${ }^{7}$ A. Siegert, Gründe hochqualifizierter russischer Transmigranten, nach Deutschland zu emigrieren. Eine empirische Studie unter russischen Akademikern, Aachen, Shaker Verlag, 2008.

8 V.J ahr, H. Schomburg and U. Teichler, Mobilität von Hochschulabsolventinnen und - absolventen in Europa, in J . Bellmann and L. Velling (eds.), Arbeitsmärkte für Hochqualifizierte. Institut für Arbeitsmarkt- und Berufsforschung der Bundesanstalt für Arbeit, No. 256, Nürnberg, J enior Verlag, 2002, p. 319.

9 F. Kalter, Stand und Perspektiven der Migrationssoziologie, in B. Orth et. al. (eds.), Soziologische Forschung: Stand und Perspektiven, Opladen, Leske und Budrich, 2003.

10 A. Portes, W. Haller and L. E. Guarnizo, Transnational Entrepreneurs: An alternative Form of Immigrant Economic Adaptation, American Sociological Review, Vol. 67, No.2, 2002, pp. 278- 298. 


\section{Methods}

Through two online surveys (N1, N2), data concerning the migration of Russian academics was collected. In order to contact interviewees, e-mail addresses of those applying for scholarships of German scientific foundations between 2000 and 2006 were used. Out of those reached, 501 (N1) and 485 (N2) answered (Table 1).

\section{Table 1: Selection of the population}

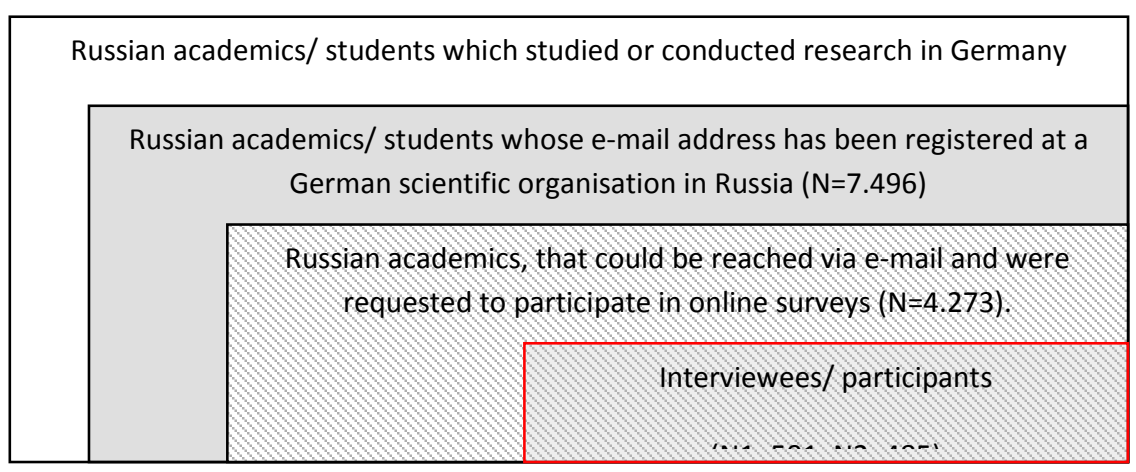

Although respondents were not explicitly asked, it can be assumed that the predominant majority were socialised and received their academic training in Russia.

Table 2: Age of interviewees when being abroad for studies/research

\begin{tabular}{|c|c|c|c|c|}
\hline \multirow[t]{2}{*}{ Age } & \multicolumn{2}{|c|}{$1^{\text {st }}$ interview (N1) } & \multicolumn{2}{|c|}{$2^{\text {nd }}$ interview (N2) } \\
\hline & Number & $\%$ & Number & $\%$ \\
\hline$<25$ years & 353 & 71,0 & 309 & 63,7 \\
\hline$>25-30$ years & 102 & 20,5 & 114 & 23,5 \\
\hline$>30$ years & 42 & 8,5 & 62 & 12,8 \\
\hline Total & 497 & 100,0 & 485 & 100,0 \\
\hline Period of questioning & \multicolumn{2}{|c|}{12 June to 03 September, 2006} & \multicolumn{2}{|c|}{12 February to 24 April, 2007} \\
\hline
\end{tabular}

Since no one has quantitatively examined the targeted group's motivation for migrating, potential reasons for migration were asked, that so far seemed not to be relevant to international research on migration. This concerns for example 'cultural closeness' - an aspect which was mentioned in pre-tests as a relevant motive by numerous Russians. A secondary analysis of sixteen one-on-one interviews from Gochberg's ${ }^{11}$ study was conducted to evaluate the relevance of various possible aspects.

It was decided to conduct interviews online despite the fact that $80 \%$ of Russia's population was without internet access in 2006. ${ }^{12}$ An important reason for this decision

11 L. M. Gochberg, op. cit.

12 H. Schmidt, K. Teubener, and N. Konradova, 'Semantic boundaries, metaphors and media usage (on the Russian Internet)', in Grenzen. Differenzierungen. Übergänge: Spannungsfelder inter- und transkultureller

Kommunikation, Konferenz der Volkswagenstiftung, J une 14- 16, 2006, Dresden, 2006, p. 22. 
was the sheer size of Russia's territory, which would make it impossible to contact alumni and conduct interviews within due course. Furthermore, carrying out on-line interviews is an efficient way of collecting data (reducing postal time, costs, and time), because it decreases transcription errors and allows interviewees to participate at their convenience.

This method ensures that results are representative. ${ }^{13}$ Since a complete inventory count was conducted, an interference-statistical analysis was not required. There are some uncertainties because the complete inventory count was exhausted to a comparatively small extend. However there is no reason to assume that the limited participation could lead to systematic distortions. Hence, there is no basis to doubt the reliability of findings. ${ }^{14}$ The volume of the sample $(\mathrm{N} 2=485)$ as well as its structure permit to derivate clear trends and findings and permit to come to conclusions through descriptive statistics.

Another methodological approach to conduct the research on the migration of highly skilled Russians was to follow the recommendation of Petersen. ${ }^{15}$ He suggests forming typologies of migrants on the basis of the data collected, in order to explain migration patterns. Thus, complexity will be reduced and contexts will be explicit. 16 In this way, groups are formed according to attributes or elements, according to which they are alike or which distinguish them from other groups. ${ }^{17}$ Specific constellations of attributes show patterns of contexts that result from the combination of selected characteristics and comparable dimensions. ${ }^{18}$ Thus, empiric patterns, correlations and connections between attributes become evident. The process of setting typologies leads to data pattern of "quasi-groups". 19

Socio-demographic attributes (e.g. gender, family status, parenthood, knowledge of foreign languages), self-assignment and mobility (N2), as well as qualification of parents (N1) of the interviewees, are used as criteria to form and compare types of migrants.

The self-assignment of the population is used as an attribute of identity as well as criteria to distinguish against other types since it is obviously an aspect "...that migrants refer (as) an attribute which they consider as relevant, typical and possible fundamental for their collective identity". ${ }^{20}$ Self-assignment was ascertained by asking: "If you would

\footnotetext{
${ }^{13}$ R. Storm, Wahrscheinlichkeitsrechnung, Mathematische Statistik, Statistische Qualitätskontrolle, $10^{\text {th }}$ edition, Munich, Hanser Verlag ,1995, p. 135.

${ }^{14} \mathrm{~J}$. Behnke, Kausalprozess und Identität. Über den Sinn von Signifikanztests und Konfidenzintervallen bei Vollerhebungen, Beiträge zu empirischen Methoden der Politikwissenschaft, Vol. 2, No. 3, 2007, p. 4.

${ }^{15}$ W. Petersen, Eine allgeMaine Typologie der Wanderung, in G. Széll (ed.), Regionale Mobilität. Nymphenburger Texte zur Wissenschaft, Vol. 10, Munich, Nymphenburger Verlagshandlung, 1972, p. 108.

16 S. Lamnek, Qualitative Sozialforschung, Vol. 1, Methodologie, 3rd edition, Weinheim, Beltz Verlag, 1995, p. 203.

${ }^{17}$ E. W. Burgess, 'Sociological research methods', American J ournal of Sociology, Vol. 50, No.6, 1945, p. 478.

18 S. Kluge, 'Empirisch begründete Typenbildung in der qualitativen Sozialforschung', in Forum Qualitative

Sozialforschung/ Forum: Qualitative Social Research, Vol.1, No.1, 2000, <http:// www.qualitative-research.net/ fqstexte/ 1-00/1-00kluge-d.htm>, accessed on 3 April, 2007, p. 2.

19 U. Schöneberg, Gestern Gastarbeiter, morgen Minderheit. Zur sozialen Integration von Einwanderern in einem "unerklärten" Einwanderungsland, Frankfurt-am-Main, Peter Lang Europäischer Verlag der Wissenschaften, 1993, p. 51.

20 R. Sackmann, T. Schultz, K. Prümm, and B. Peters, Kollektive Identitäten, Frankfurt-am-Main, Peter Lang Europäischer Verlag der Wissenschaften, 2005, p. 207. 
have to decide, as which part of society you would define yourself when being in Germany?: (a) As part of the international scientific community; (b) As part of the Russian society in Germany, (c) As part of the German society, (d) None, (e) As a bit of everything; or (f) Completely independent". The typology of 'Individualists' consisted of those, who decided onto the options (d), (e) or (f).

To determine the geographical mobility of the population, the interviewees were asked: "If I would have the chance in life, I would like to...: (a) life for sometime abroad, (b) frequently life abroad, (c) permanently life abroad or (d) only life in Russia”.

The values and networks of the interviewees were determined through various and differentiated questions. Out of the given answers and background interviews, the following typologies and patterns were composed (Table 3):

\section{Table 3: Typologies 21}

\begin{tabular}{|c|c|c|c|}
\hline Global Scientists & Individualists & Germanophile & Patriots \\
\hline $\begin{array}{l}\text { Release themselves from } \\
\text { their society of origin } \\
\text { without aiming to } \\
\text { permanently settle in } \\
\text { another society. }\end{array}$ & $\begin{array}{l}\text { Want to travel around } \\
\text { the world. }\end{array}$ & $\begin{array}{l}\text { Prefer to life and work } \\
\text { in Germany. }\end{array}$ & $\begin{array}{l}\text { Prefer to life and work in } \\
\text { Russia. }\end{array}$ \\
\hline $\begin{array}{l}\text { Scientific work is central } \\
\text { part of their identity. }\end{array}$ & $\begin{array}{l}\text { Are aiming to self-realise } \\
\text { themselves. }\end{array}$ & $\begin{array}{l}\text { Their love to Germany and/or the German } \\
\text { language offers them focus and potential of } \\
\text { identification. }\end{array}$ & $\begin{array}{l}\text { They identity themselves } \\
\text { through their society } \\
\text { of origin. }\end{array}$ \\
\hline $\begin{array}{l}\text { They are mobile between } \\
\text { their society of origin and } \\
\text { other countries. }\end{array}$ & $\begin{array}{l}\text { Their mobility is geographically } \\
\text { almost not } \\
\text { limited. }\end{array}$ & $\begin{array}{l}\text { Their mobility is limited: They want to leave } \\
\text { their parental society and aim at integrating } \\
\text { themselves into the German society. }\end{array}$ & $\begin{array}{l}\text { Their mobility is very } \\
\text { limited; Stays abroad are } \\
\text { seen as necessity to } \\
\text { improve their living } \\
\text { standard at home } \\
\text { (e.g. by improving } \\
\text { language competencies) }\end{array}$ \\
\hline $\begin{array}{l}\text { They globally set up } \\
\text { professional networks, } \\
\text { even if they got preferences } \\
\text { towards certain societies. }\end{array}$ & $\begin{array}{l}\text { They are interested to learn/ get } \\
\text { to know new things. }\end{array}$ & $\begin{array}{l}\text { Networking on personal basis is meant to } \\
\text { support them settling for good in Germany. }\end{array}$ & $\begin{array}{c}\text { They improve their } \\
\text { competencies abroad just } \\
\text { to be more competitive at } \\
\text { home. }\end{array}$ \\
\hline $\begin{array}{l}\text { It is their ambition to } \\
\text { improve their professional } \\
\text { skills, knowledge and } \\
\text { qualification in order to } \\
\text { globally compete } \\
\text { successfully. }\end{array}$ & $\begin{array}{l}\text { They are trying to expand their } \\
\text { competencies and to compete } \\
\text { beyond their home country. }\end{array}$ & $\begin{array}{c}\text { They are aiming at improving their chances } \\
\text { to integrate into the German society and } \\
\text { permanently settling there by gaining goal- } \\
\text { oriented skills. }\end{array}$ & $\begin{array}{l}\text { Their readiness to } \\
\text { compete is limited and } \\
\text { concentrates on improving } \\
\text { their chances in their } \\
\text { home-country. }\end{array}$ \\
\hline $46,1 \%(\mathrm{~N}=222)$ & $38,0 \%(\mathrm{~N}=183)$ & $12,7 \%(\mathrm{~N}=61)$ & $3,3 \%(\mathrm{~N}=16)$ \\
\hline
\end{tabular}

This article focuses on socio-demographic attributes, motives for migrating, selfassignments (N2) and parental qualification (N1) of those who were younger then 25 (Table 2) when they first went abroad. Their data will be compared with the data of all other interviewees ( $>25$ years).

\footnotetext{
${ }^{21}$ A. Siegert, Gründe hochqualifizierter russischer Transmigranten, nach Deutschland zu emigrieren. Eine empirische Studie unter russischen Akademikern, Aachen, Shaker Verlag, 2008, p. 171.
} 
Although participants in the first and second surveys originate from the same sample, they are not identical. Therefore survey data of N1 and N2 may only be compared but cannot be correlated - although they largely comply.

Datasets have been analysed through Spearman's Coefficient of Rank Order. It shows connections between the age group of those below 25 years and its comparison group ( $>25$ years) on ordinal scaled attributes. This means that the more attributes of these groups vary, the stronger the results may deviate from +1 (identical behaviour). The value of factor ' $r 2$ ' is given in brackets. It gives, according to Spearman's formula, the potentiated value of differences in rankings, compared to those above 25 years.

\section{Migration after the Collapse of the Soviet Union}

The collapse of the Soviet Union allowed its citizens the opportunity to travel or migrate freely. Many highly qualified scientists made use of this opportunity and left their home country.

\section{The extent of 'brain drain'}

In 1997, Salt ${ }^{22}$ assumed that the migration of Russian students and highly qualified individuals would increase. In 1995, Tikhonov ${ }^{23}$ came to the conclusion that half of the highly qualified staff of the Russian military industry was ready to emigrate. The World Bank report in 2005 found out that since the Soviet Union broke down, 1.1 million Russians had left. ${ }^{24}$ There was a noticeable brain drain' due to emigration. Hefele and Menz $^{25}$ quote estimated that in the 1990s, economic losses due to emigration from the CIS states amounted to 60-75 billion US Dollars. Wolburg ${ }^{26}$ also published his estimates of highly qualified Eastern European migrants. To produce his conclusions, he had to partially rely on earlier sources. However, the actual flow of migration could be overestimated in his study. Russian migration was restricted for decades, and many highly qualified people, who had wanted to leave the country in the past, were not embarking on migration as soon as the chance arose. This means emigration may not increase in a linear fashion in the future.

\section{a. Countries of destination for Russian migrants}

Germany was for many years, and still is, one of the preferred countries of destination for Russian academics who emigrate. ${ }^{27}$ (Table 4)

\footnotetext{
22 J . Salt, op.cit., p. 22

${ }^{23}$ V. Tikhonov, 'Migration potential with Russia's military-industrial complex', Studi Emigrazione, No. 117, 1995, pp. 128- 143 .

24 The World Bank, From Transition to Development, A Country Economic Memorandum for the Russian Federation, Moscow, 2005, p. 57.

${ }^{25}$ N. Hefele and M. Menz, 'Wer integriert die Hochqualifizierten?, Integration russischsprachiger Akademikerinnen', Migration und soziale Arbeit, Vol. 28, No. 3/4 2006, pp. 302- 309 (p.303).

${ }^{26}$ M. Wolburg, On Brain Drain, Brain Gain and Brain Exchange within Europe, HWWA Studies of the Hamburg Institute of International Economics, No. 61, Baden-Baden, Nomos Verlagsgesellschaft, 2001, p. 300.

${ }^{27}$ A. Mitschugina and M. Rachmaninowa, Über die Veränderung der Bevölkerungszahl in der Russischen Föderation im J ahr 1996, Vol. 98, Wiesbaden, The Bundesinstitut für Bevölkerungsentwicklung, 2000, p. 114.
} 
Table 4: Countries of destination of Russian scientists according to Gochberg ${ }^{28}$

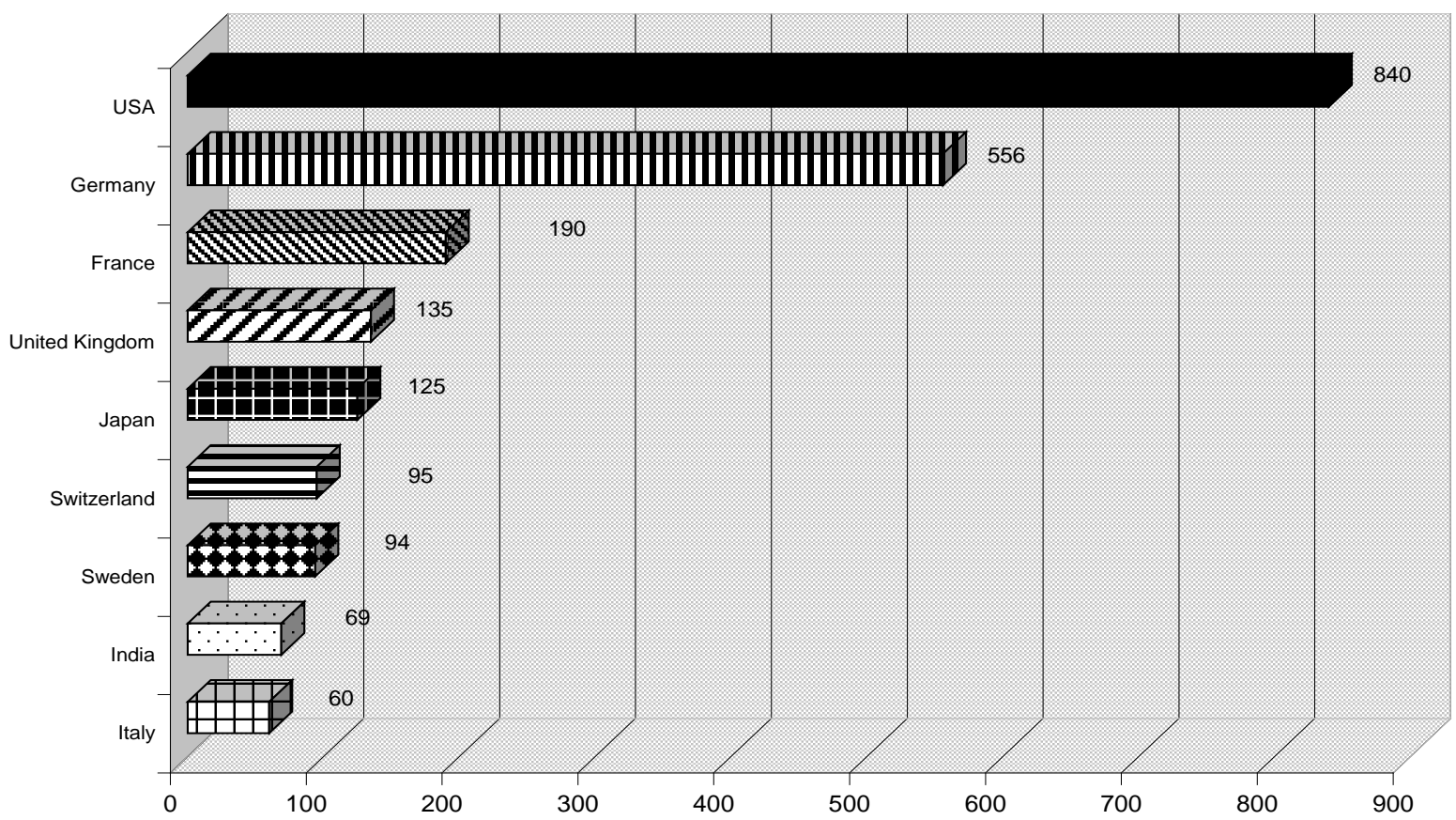

It is interesting that for Russian academic migrants a positive image of a potential destination is of great importance. Thus, countries not typically associated with immigration -- e.g. Canada, Australia or Great Britain -- are on the first ranks (Gochberg 2005). The question remains; why Russian migrants have such a positive image of Germany? And exactly what image do people living in Russia today have of Germany?

According to a representative poll of the 'Gesellschaft für Konsumforschung' conducted in May 2006,29 Germans enjoy a positive reputation in Russia. 30 This seems surprising, since only $4.6 \%$ of the interviewees have been to Germany once or twice, $0.4 \%$ was in Germany three to five times and just $0.5 \%$ have visited the country more then five times. The percentage of Russian citizens spending nights in hotels located in Germany did not exceed $1.8 \%$ in 2005.31

It is obvious that a positive opinion for the majority of Russia's population about Germany does not derive from personal impressions and experiences. This can be no surprise, because "in everyday life there is no grave difference between reality and perception of reality. One tends to take for real what one believes to see ...This process

\footnotetext{
${ }^{28}$ L. M. Gochberg, Vosproizvodstvo naučnoj èlity v Rossii. Rol' zarubežnych naučnych fondov, Moscow, Frontera, 2005, p. 43.

${ }^{29}$ Gesellschaft für Konsumforschung (GfK, Nürnberg), Was ist deutsch? Das Image der Deutschen in Deutschland und in Europa, Nürnberg, 2006.

30 Ibid, p. 10.

31 Ibid, p. 6.
} 
of perceived reality is, what people consider to be prejudices". ${ }^{2} \mathrm{Li}$ ßmann et. al conclude that prejudices and attitudes of people on others are set according to patterns of cognition. People will "...in particular perceive information that matches the pattern they already got and deviating data will not be recognised or will be interpreted according to already existing prejudices". 33 They are certain that this is the base of processes within societies and founded patterns of perception. ${ }^{34}$

Those patterns of perception could be used to explain visions of Germany and Germans by Russians who has never visited the country or met its citizens. Germany was mostly perceived as an economic power and producer of high-quality products. ${ }^{35}$ Furthermore, Russians valued Germany's social security and democracy and considered it a "developed and civilised country". ${ }^{36}$ Additionally, Russians believed Germans had friendly attitudes towards them. When asked which country is most friendly with Russia, Germany was mentioned most frequently (15\%). ${ }^{37}$ Surveys of the Central Russian Centre of Consultation (Mittelrussisches Beratungszentrum), showed that Germany and China were the only two countries that have been seen for many years as having friendly attitudes towards Russia. ${ }^{38}$

Polls and surveys of TNS Emnid ${ }^{39}$ taken at different times showed that the reputation of Germany depended on contexts. How, then, can such a detailed picture of Germany evolve without personal experiences? What is the history of migration between the two countries? Apart from historical migration between Russia and Germany, ${ }^{40}$ there have been four other ways for their citizens to exchange values, traditions, and stories in the recent past: (a) soldiers of the Soviet Army returning from the GDR, ${ }^{41}$ (b) scientific exchange between the GDR and the Soviet Union, ${ }^{42}$ (c) "Russo-Germans" returning to West Germany, 43 and (d) Russian J ews being granted resident visa to West Germany. ${ }^{4}$

\footnotetext{
${ }^{32}$ H. J . Lißmann, H. Nicklas, and Ä. Ostermann, Feindbilder in Schulbüchern, in: Friedensanalysen, Für Theorie und Praxis 1, Schwerpunkt: Feindbilder, Frankfurt-am-Main, Edition Suhrkamp, 1975, pp.37- 62

33 Ibid., p.37.

34 Ibid., p.40.

35 Gesellschaft für Konsumforschung, op.cit., p. 16.

36 Ibid., p. 22.

${ }^{37}$ Friedrich-Ebert-Stiftung, Russland - ein Selbstbild, Was eint die Russen, wie beurteilen sie Russlands Zeitgeschichte und was erwarten sie für Russlands Zukunft?, 2005, Moscow, 2005, p. 13. The positive perception is followed by France (12\%), China (9\%), India (7\%), USA and Belorussia (each 6\%), J apan and Great Britain (each 4\%) (Ibid.)

38 Ibid.

39 TNS Emnid, op. cit.

40 T. Waters, Towards a Theory of Ethnic Identity and Migration: The Formation of Ethnic Enclaves by Migrant Germans in Russia and North America, International Migration Review, Vol. 29, No. 2, 1995, pp. 515- 544. Waters research covers the history of migration over the past 300 years between the two countries.

${ }^{41}$ S. Satjukow, Sowjetische Streitkräfte und DDR-Bevölkerung. Methodologische Überlegungen zur Erforschung einer kollektiven Beziehungsgeschichte, pp. 193- 213, in H. Timmermann (ed.), Agenda DDR-Forschung. Ergebnisse, Probleme, Kontroversen, LIT-Verlag Münster, 2005.

42 B. Last and H.-D. Schaefer, Die Wissenschaftsbeziehungen der Hochschulen der ehemaligen DDR mit Osteuropa, Berlin, Verlag Constructiv, 1992; N. N. Sofinski, 'Mit Stolz begeht das sowjetische Hochschulwesen den 50. J ahrestag der UdSSR', Das Hochschulwesen, Berlin, No. 12, 1972, pp. 356- 361.

43 P. A. Harris, 'Russische J uden und Aussiedler: Integrationspolitik und lokale Verantwortung', in Aussiedler, deutsche Einwanderer aus Osteuropa, IMIS-Schriften 8, 2nd edition, Göttingen, V\&R Unipress, 2003.

${ }^{44}$ M. Tress, 'Foreigners or J ews? The Soviet J ewish Refugee Populations in Germany and the United States', in East European J ewish Affairs, Vol. 27, No. 2, 1997, pp. 21- 38.
} 
It seems that German re-unification fostered a positive relationship between Germany and Russia, and impressions gained from Russian's experiences with the GDR were transformed onto the unified Germany. It seems plausible, given the number of people involved, that the four episodes of recent migration contributed to Germany's reputation in Russia today. Although this reputation is not based on personal experience among the majority of Russian population, it is communicated within social contexts and serves as a background on which hopes and wishes of the potential migrants are projected.

\section{Results of Survey}

Schäfers 45 defines youth as "the age group of those who are between 13 to 25 years old" who show common patterns of behaviour and values. Below, it will be examined if and to what extent Russian academics in this age group have things in common when it comes to migration. To do this, such criteria as socio-demographical attributes, motives to migrate, possible countries of destination, reasons to learn foreign languages and highest parental qualification will be compared. Data collected from interviewees below 25 years $(\mathrm{N}=309)$ will be checked against data of those older then 25 years $(\mathrm{N}=176)$.

Differences in socio-demographic attributes between the two groups are not pronounced. There is a slightly higher share of women among those younger than 25 years (69.6\%; comparison group 63.7\%). Predictably, the share of interviewees who are married and/ or have children increases the older they are. However, when you look at the academic qualifications of participants' parents, clear differences show up. The younger the interviewees are, the higher the percentage who have academically qualified parents (Table 5):

Table 5: Parental academic qualification

\begin{tabular}{|c|c|c|c|c|c|}
\hline & & \multicolumn{4}{|c|}{ age when leaving Russia } \\
\hline & & & $25-30$ & & \\
\hline & & $<25$ years & years & $>30$ years & total \\
\hline & & $\%$ & $\%$ & $\%$ & $\%$ \\
\hline \multirow{3}{*}{$\begin{array}{l}\text { Did father receive } \\
\text { an academical } \\
\text { degree? }\end{array}$} & no & 33.1 & 45.1 & 35.7 & 35.8 \\
\hline & yes & 66.9 & 54.9 & 64.3 & 64.2 \\
\hline & total & 100.0 & 100.0 & 100.0 & 100.0 \\
\hline \multirow{3}{*}{$\begin{array}{l}\text { Did mother receive } \\
\text { an academical } \\
\text { degree? }\end{array}$} & no & 29.7 & 37.3 & 54.8 & 33.4 \\
\hline & yes & 70.3 & 62.7 & 45.2 & 66.6 \\
\hline & total & 100.0 & 100.0 & 100.0 & 100.0 \\
\hline
\end{tabular}

Gained socio-demographic differences in regards of formal qualifications can be explained through age (Table 6):

${ }^{45}$ B. Schäfers, 'J ugend', in B. Schäfers (ed.), Grundbegriffe der Soziologie, $5^{\text {th }}$ edition, Opladen, Leske und Budrich, 1998, p.159. 
Table 6: Highest qualification of the interviewees

\begin{tabular}{llrrrr}
\hline \hline & & & $25-30$ & & \\
& & $<25$ years & years & $>30$ years & \multicolumn{1}{c}{ total } \\
\hline highest & Professor & $.6 \%$ & $1.8 \%$ & $40.3 \%$ & $6.0 \%$ \\
academical & Dr/PhD & $13.6 \%$ & $52.6 \%$ & $27.4 \%$ & $24.6 \%$ \\
& Magister & $11.4 \%$ & $14.9 \%$ & $4.8 \%$ & $11.4 \%$ \\
& MBA/MBSc & $2.9 \%$ & $.9 \%$ & $3.2 \%$ & $2.5 \%$ \\
& Diplom & $42.2 \%$ & $28.9 \%$ & $22.6 \%$ & $36.6 \%$ \\
& Bachelor & $11.7 \%$ & $.0 \%$ & $.0 \%$ & $7.4 \%$ \\
& others & $17.5 \%$ & $.9 \%$ & $1.6 \%$ & $11.6 \%$ \\
& total & $100.0 \%$ & $100.0 \%$ & $100.0 \%$ & $100.0 \%$ \\
\hline \hline
\end{tabular}

More often than older interviewees, those below 25 years mentioned that their parents (55.1\%; age 25-30 years: $39.5 \%$; age over 30 years: $37.7 \%)$ and relatives (7.3\%; age 2530 years: $4.4 \%$; age over 30 years: $6.6 \%$ ) influenced their decision to learn a foreign language. However, the influence of teachers declined: $39.2 \%$ influenced those younger then 25 years, $54.5 \%$ between $25-30$ years and $49.2 \%$ of those over 30 years. It also became obvious that there is a tendency towards multilingual competencies and, that the average age at which they start to learn a foreign language decreases (Table 7):

Table 7: Age when the first foreign language was taught

\begin{tabular}{|c|c|c|c|c|c|c|c|c|c|}
\hline & & \multicolumn{2}{|c|}{$<25$ years } & \multicolumn{2}{|c|}{$25-30$ years } & \multicolumn{2}{|c|}{$>30$ years } & \multicolumn{2}{|c|}{ total } \\
\hline & & mean & $\begin{array}{l}\text { standard } \\
\text { deviation }\end{array}$ & mean & $\begin{array}{l}\text { standard } \\
\text { deviation }\end{array}$ & mean & $\begin{array}{l}\text { standard } \\
\text { deviation }\end{array}$ & mean & $\begin{array}{l}\text { standard } \\
\text { deviation }\end{array}$ \\
\hline how old & first language & 8.96 & 2.721 & 9.90 & 2.934 & 10.87 & 4.163 & 9.43 & 3.063 \\
\hline $\begin{array}{l}\text { were you } \\
\text { when }\end{array}$ & second lang. & 16.19 & 4,785 & 19.85 & 5.111 & 25.43 & 9.031 & 18.15 & 6.326 \\
\hline starting to & third lang. & 19.39 & 4,206 & 22.51 & 7,026 & 36.44 & 8.116 & 21.41 & 7.027 \\
\hline $\begin{array}{l}\text { learn a } \\
\text { foreign }\end{array}$ & fourth lang. & 19.76 & 5,757 & 21.55 & 9.761 & 33.25 & 4.031 & 20.81 & 7.098 \\
\hline language? & fifth lang. & 19.83 & 7,335 & 21.20 & 13.535 & 9.50 & 12.021 & 19.39 & 8.815 \\
\hline
\end{tabular}

Professional career and the opportunity to have contacts abroad seem to be a high motivation for younger Russian academics to learn a foreign language. This aspect distinguishes them from older academics, who are motivated because they want to understand scientific texts (Table 8): 
Table 8: Reasons for learning foreign languages

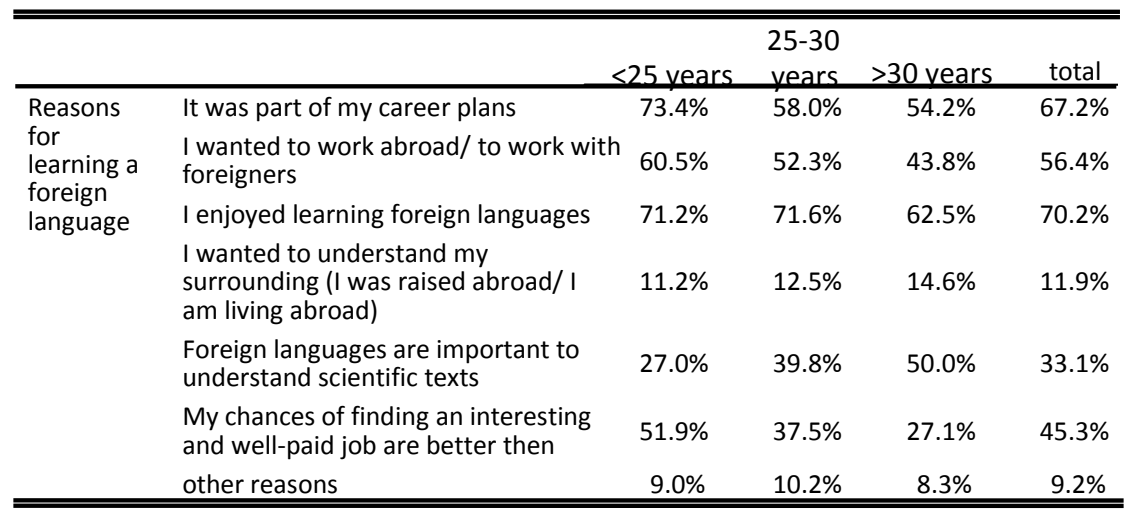

There are, however, no differences among the age groups in terms of their preferred immigration destinations (Table 9). This should be no surprise, as the decision on which foreign language to learn already prejudices the potential destination of migrants and is further concretised by applying for a German scholarship.

\section{Table 9: Preferred countries of migration}

\begin{tabular}{|c|c|c|c|c|}
\hline & \multicolumn{4}{|c|}{ Age } \\
\hline & $<25$ years & $\begin{array}{l}25-30 \\
\text { years }\end{array}$ & $>30$ years & Total \\
\hline & $\%$ & $\%$ & $\%$ & $\%$ \\
\hline Germany & $62,6 \%$ & $67,7 \%$ & $60,5 \%$ & $63,6 \%$ \\
\hline USA & $7,0 \%$ & $7,5 \%$ & $9,3 \%$ & $7,4 \%$ \\
\hline United Kingdom & $4,5 \%$ & $5,4 \%$ & ,O\% & $4,2 \%$ \\
\hline France & ,4\% & $3,2 \%$ & $4,7 \%$ & $1,6 \%$ \\
\hline Spain & $2,1 \%$ & , O\% & $2,3 \%$ & $1,6 \%$ \\
\hline Canada & $2,1 \%$ & $3,2 \%$ & $4,7 \%$ & $2,6 \%$ \\
\hline Australia & $1,2 \%$ & ,O\% & ,O\% & ,8\% \\
\hline Malaysia & ,8\% &, $0 \%$ &, $0 \%$ &, $5 \%$ \\
\hline Netherlands & $2,1 \%$ &, $0 \%$ & $2,3 \%$ & $1,6 \%$ \\
\hline Japan &, $4 \%$ &, $0 \%$ &, $0 \%$ & , 3\% \\
\hline South Africa &, $4 \%$ &, $0 \%$ &, $0 \%$ & , 3\% \\
\hline Norway & $1,2 \%$ & $1,1 \%$ &, $0 \%$ & $1,1 \%$ \\
\hline Switzerland & $4,5 \%$ & $4,3 \%$ & $4,7 \%$ & $4,5 \%$ \\
\hline Ireland &, $0 \%$ & $1,1 \%$ &, $0 \%$ & , 3\% \\
\hline Italy & $2,5 \%$ & $2,2 \%$ &, $0 \%$ & $2,1 \%$ \\
\hline Greece &, $0 \%$ &, $0 \%$ & $2,3 \%$ &, $3 \%$ \\
\hline China & $1,2 \%$ &, $0 \%$ &, $0 \%$ & ,8\% \\
\hline South Corea &, $0 \%$ &, $0 \%$ &, $0 \%$ & ,0\% \\
\hline Turkey &, $0 \%$ &, $0 \%$ &, $0 \%$ & ,O\% \\
\hline Sweden &, $8 \%$ &, $0 \%$ & $2,3 \%$ &, $8 \%$ \\
\hline Others & $6,2 \%$ & $4,3 \%$ & $7,0 \%$ & $5,8 \%$ \\
\hline Total & $100,0 \%$ & $100,0 \%$ & $100,0 \%$ & $100,0 \%$ \\
\hline
\end{tabular}

There are also no differences between age groups as far as it concerns their academic networks. Great discrepancies are noticeable, however, between those younger then 31 years and those 31 years or older when it comes to private networking. Apparently social networks are of less importance to those Russian academics who are older than 30 years, when being abroad. 
Discrepancies in self-assignments between age groups indicate that phases of personality development are already completed among elder interviewees (Table 10). They have found their place in society and positioned themselves. In contrast to elder participants, those academics younger then 25 years covered a wider range of options to assign themselves during their stay abroad.

\section{Table 10: Self-assignments to communities when being in Germany}

\begin{tabular}{lrrrr}
\hline \hline & $<25$ years & \multicolumn{1}{c}{$\begin{array}{l}25-30 \\
\text { years }\end{array}$} & \multicolumn{1}{c}{$>$ 30 years } & \multicolumn{1}{c}{ total } \\
\hline part of the global scientific community & $40.8 \%$ & $51.8 \%$ & $61.3 \%$ & $46.1 \%$ \\
individualists: "none of the given & $4.6 \%$ & $4.4 \%$ & $1.6 \%$ & $4.1 \%$ \\
answers" & $19.0 \%$ & $15.8 \%$ & $19.4 \%$ & $18.3 \%$ \\
individualists: "a bit of everything" & $18.3 \%$ & $13.2 \%$ & $6.5 \%$ & $15.6 \%$ \\
individualists: "completely on my own" & $13.4 \%$ & $12.3 \%$ & $9.7 \%$ & $12.7 \%$ \\
part of the German community & $3.9 \%$ & $2.6 \%$ & $1.6 \%$ & $3.3 \%$ \\
patriots & $100.0 \%$ & $100.0 \%$ & $100.0 \%$ & $100.0 \%$ \\
total & & & & \\
\hline \hline
\end{tabular}

Youth ( $<25$ years) who participated in the study were only slightly more motivated to migrate than other age groups. There were only a few differences in reasons for migrating, but they were significant (Table 11). 


\section{Table 11: Differences in reasons to migrate}

\begin{tabular}{|c|c|c|c|c|c|}
\hline & & $\begin{array}{c}\text { age } \\
\text { below } 25\end{array}$ & $\begin{array}{c}\text { age } 25 \text { to } \\
30\end{array}$ & $\begin{array}{c}\text { age more } \\
\text { than } 30\end{array}$ & total \\
\hline \multirow{29}{*}{$\begin{array}{l}\text { I decided to study/ } \\
\text { do researches in } \\
\text { Germany because }\end{array}$} & $\begin{array}{l}\text { I experienced discrimination and/ or persecution in } \\
\text { Russia }\end{array}$ &, $7 \%$ & $1,8 \%$ & $3,2 \%$ & $1,2 \%$ \\
\hline & $\begin{array}{l}\text { the possibilities of earning a good salary during studies } \\
\text { were better over there }\end{array}$ & $15,7 \%$ & $19,3 \%$ & $16,1 \%$ & $16,6 \%$ \\
\hline & I got already personal contacts (e.g. friends, relatives) & $20,3 \%$ & $19,3 \%$ & $22,6 \%$ & $20,3 \%$ \\
\hline & it was important for my childrens future & $9,8 \%$ & $7,0 \%$ & $9,7 \%$ & $9,1 \%$ \\
\hline & I got positive impressions of Germany & $67,0 \%$ & $57,9 \%$ & $62,9 \%$ & $64,3 \%$ \\
\hline & I was granted a scholarship & $78,4 \%$ & $89,5 \%$ & $75,8 \%$ & $80,7 \%$ \\
\hline & I did not need to pay fees to enrole myself & $15,4 \%$ & $8,8 \%$ & $4,8 \%$ & $12,4 \%$ \\
\hline & $\begin{array}{l}\text { the scientific level was better then at the university of } \\
\text { my home country }\end{array}$ & $29,1 \%$ & $25,4 \%$ & $25,8 \%$ & $27,8 \%$ \\
\hline & I wanted to get married to a German partner &, $7 \%$ &, $0 \%$ &, $0 \%$ &, $4 \%$ \\
\hline & $\begin{array}{l}\text { it seems to me that Germany is culturally close to } \\
\text { Russia }\end{array}$ & $23,2 \%$ & $24,6 \%$ & $32,3 \%$ & $24,7 \%$ \\
\hline & $\begin{array}{l}\text { the juridical options (working permit, visa) to stay in } \\
\text { Germany were better than elsewhere }\end{array}$ & $2,0 \%$ & $2,6 \%$ &, $0 \%$ & $1,9 \%$ \\
\hline & $\begin{array}{l}\text { my competency in German was better then in other } \\
\text { foreign languages }\end{array}$ & $53,6 \%$ & $43,9 \%$ & $43,5 \%$ & $50,0 \%$ \\
\hline & the country seems politically stable & $19,6 \%$ & $24,6 \%$ & $24,2 \%$ & $21,4 \%$ \\
\hline & it was important for my career plans & $61,8 \%$ & $60,5 \%$ & $56,5 \%$ & $60,8 \%$ \\
\hline & Germany is not that far from Russia & $12,4 \%$ & $24,6 \%$ & $17,7 \%$ & $16,0 \%$ \\
\hline & $\begin{array}{l}\text { I got more information on this country, then I got of } \\
\text { other countries }\end{array}$ & $30,7 \%$ & $27,2 \%$ & $27,4 \%$ & $29,5 \%$ \\
\hline & $\begin{array}{l}\text { relatives/ acquaintances/ friends talked positively about } \\
\text { Germany }\end{array}$ & $20,9 \%$ & $23,7 \%$ & $21,0 \%$ & $21,6 \%$ \\
\hline & ecology is better then in Russia & $10,8 \%$ & $11,4 \%$ & $8,1 \%$ & $10,6 \%$ \\
\hline & quality and comfort of life are better over there & $29,4 \%$ & $32,5 \%$ & $30,6 \%$ & $30,3 \%$ \\
\hline & $\begin{array}{l}\text { I find that a functioning juridical system, freedom and } \\
\text { strong democracy are important }\end{array}$ & $20,3 \%$ & $15,8 \%$ & $21,0 \%$ & $19,3 \%$ \\
\hline & $\begin{array}{l}\text { a Russian community exists over there, to which I got/ } \\
\text { seek contact }\end{array}$ & $1,6 \%$ &, $9 \%$ & $4,8 \%$ & $1,9 \%$ \\
\hline & $\begin{array}{l}\text { there is an international scientific community that } \\
\text { interests me }\end{array}$ & $21,9 \%$ & $43,0 \%$ & $45,2 \%$ & $29,9 \%$ \\
\hline & I value German mentality and values & $45,1 \%$ & $46,5 \%$ & $48,4 \%$ & $45,9 \%$ \\
\hline & working conditions are better in Germany & $20,9 \%$ & $37,7 \%$ & $27,4 \%$ & $25,7 \%$ \\
\hline & $\begin{array}{l}\text { professors/ colleagues/ scientific staff were better } \\
\text { qualified }\end{array}$ & $18,0 \%$ & $17,5 \%$ & $16,1 \%$ & $17,6 \%$ \\
\hline & $\begin{array}{l}\text { income opportunities after university are better over } \\
\text { there }\end{array}$ & $17,6 \%$ & $15,8 \%$ & $8,1 \%$ & $16,0 \%$ \\
\hline & sciences and research got a better image in Germany & $35,6 \%$ & $46,5 \%$ & $53,2 \%$ & $40,5 \%$ \\
\hline & I want to travel the world; this is easier from Germany & $33,3 \%$ & $32,5 \%$ & $24,2 \%$ & $32,0 \%$ \\
\hline & $\begin{array}{l}\text { with my grant/ scholarship I can support my family in } \\
\text { Russia }\end{array}$ & $7,5 \%$ & $7,9 \%$ & $17,7 \%$ & $8,9 \%$ \\
\hline
\end{tabular}

Comparing selected reasons to migrate to Germany between age groups, Spearman's Coefficient of Rank Order makes it clear that there are strong divergences (difference in rank order $>3$ respectively $r^{2}>9$ ) regarding the following aspects: 
1. Those younger than 25 years value the fact that there are no university fees in Germany, whereas those older than 30 years do not pay much attention to this aspect ( $\left.r^{2} 36\right)$.

2. The geographical distance between the country of origin and the place to study is less important to youth ( $<25$ years) than, in particular, to those who are between 25 and 30 years old $\left(r^{2} 49\right)$.

3. Positive opinions of the social surrounding in Germany do have a stronger impact on young academics ( $<25$ years) than on those who are between 25 and 30 years old $\left(r^{2}\right.$ 12.25). Comparing those two age groups, values like "right of law, liberty/ freedom, democracy" have a much stronger impact on decisions to migrate on youth $\left(\mathrm{r}^{2}\right.$ 36.00).

4. The attractiveness of Germany's scientific community is obviously stronger the older Russian academics are. Interviewees older than 30 years ( $\left.\mathrm{r}^{2} 36.00\right)$, as well as those who are between 25 to 30 years old ( $\left.\mathrm{r}^{2} 25.00\right)$, pay much more attention to this criteria when deciding on where to migrate to than youth ( $<25$ years) does. By the way, this also applies to scientific working conditions, which are much more appreciated by participants who are 25 to 30 years old ( $\mathrm{r}^{2}$ 20.25). Respondents older then 30 years valued, in particular, the qualification of professors that they considered to be better than in Russia ( $r^{2}$ 12.25).

5. From looking at reasons for learning foreign languages, it is clear how much more career-oriented young academics are. This becomes even more obvious when respondents elaborate their decision to be located in Germany. Compared to those above 30 years, youth ( $<25$ years) stresses on income perspectives after their studies as a reason to decide to b e in Germany ( $\left.\mathrm{r}^{2} 30.25\right)$.

6. Another important reason especially for young Russian academics is the opportunity to gain new impressions and to travel "from Germany around the world". This indicates differences in personality developments and values compared to the age group older then 30 years ( $\mathrm{r}^{2}$ 42.25).

7. Obligations towards their families are important reasons to study abroad for alumni older then 30 years $\left(r^{2} 42.25\right)$. For them a scholarship offers an opportunity to support their relatives who stayed behind in Russia.

\section{Intermediary Result}

Socio-demographic differences in attributes (e.g. family status) between the age groups can be largely explained as age-related. Other aspects, however, indicate clear divergences. For example, chances that young interviewees have parents with academic qualifications are much higher than those of older participants. Parents, relatives and friends of young interviewees ( $<25$ years) strongly influenced their choice of foreign language to learn. In parallel, the influence of teachers declined. Young Russian academics considered having a foreign language to be a criterion that had an impact on their professional perspectives, opportunity to work abroad or make contacts in other countries. Russian academics younger then 31 years also valued (Russian) Diaspora networks more then older academics did. The latter rather focus on networks of scientific communities. 
There were no noticeable divergences between age groups in terms of preferred places to emigrate. However, importantly, despite diversity on personal level, respondents of this study were members of one (rather homogenous) sample. Significantly, when it comes to reasons to migrate to Germany, clear differences among age groups were obvious. Interviewees below 25 years seemed to be more open towards the so-called "Western" values. Some of the given motives to migrate indicated that developments of the younger respondents' personalities were not yet completed. Other results showed that interviewees had not yet established their own family (they were not yet married \& had no children). Working conditions of Germany's scientific community were clearly more important to older Russian academics.

\section{Selected Theoretical Explanations for Reasons to Migrate}

Results of this study confirm that there are processes of differentiation among reasons to migrate, as Frühwald ${ }^{46}$ already observed. Arguably, several theories about migration are able to explain the results of this survey.

\section{a. Is it only the Homo Economicus that migrates?}

The assumption that people -- as 'Homo economicus' - use only economic motives to weigh pros and cons of migration is a theoretical construction that cannot be confirmed by the findings of this survey. ${ }^{47}$ This study showed that socio-economic reasons by themselves can not explain why people move on or stay in their home countries and that migration processes are a result of complex human behaviour. ${ }^{48}$ Respectively, this study looks at the arguments by leading German sociologists to discuss the motives to migrate (assuming that some of them could be pertinent to the presented here case-study of migrating to Germany Russian academics).

\section{b. Attractiveness of I mmigration Countries}

Treibelassumes that modern regions and societies are attractive for migrants and that the importance of kin in relationships declines. 49 There are numerous indicators that illustrate that Russian academics leave their home country in order to improve their living and working conditions or the prospects for their children. This, however, is a clear argument against reduced relevance of family bonds (as argued e.g. by Beck). ${ }^{50}$ The findings for this sample proved a strong influence of social surroundings when it comes to selecting a foreign language or an immigration country. It furthermore evinces that a large number of interviewees are prepared to live abroad in order to financially support their families. Whether it really is the modernity, as Treibel ${ }^{51}$ assumes, (which would still needs to be defined) of regions or societies that attract migrants can neither be confirmed nor denied. This could be a focus of future studies of Russian academic

46 W. Frühwald, 'Begehrt wie Fußballer', Die Zeit, No. 36, August 30, 2007, p. 71.

${ }^{47}$ A. Treibel, Migration in modernen Gesellschaften, 3d edition; München/ Weinheim, Juventa Verlag, 2003 , p. 39.

${ }^{48}$ R. Feithen, Arbeitskräftewanderungen in der Europäischen GeMainschaft. Bestimmungsgründe und regionalpolitische Implikationen, Forschungsberichte des Instituts für Bevölkerungsforschung und Sozialpolitik (IBS), Universität Bielefeld, Vol. 9, Frankfurt-am-Main, Campus Verlag, 1985, p. 55.

${ }^{49}$ A. Treibel, op.cit, p. 13.

50 U. Beck, Risikogesellschaft. Auf dem Weg in eine andere Moderne; Frankfurt-am-Main, Suhrkamp Taschenbuch Wissenschaft, 1986.

51 A. Treibel, op.cit., p. 13. 
migration. Also, future studies examine whether or to what extend these findings are bound to cultural contexts that prevail in societies of origin.

\section{c. Social networks as motives to migrate}

For quite some time, it has been assumed that networks stimulate migration. Portes and Ruben 52 argued the impact of networks on migration is so strong that it dominates other potential influences. It is suggested that networks' efficiency and importance is in their ability to establish "netting of social relationships (which are)... seen as an entity influences the behaviour of all connected social units and can thus be used to interpret behaviour". ${ }^{53}$ Evidently there is a strong impact by social networks on socialisation on values, life styles and goals to be achieved in life.

This study delivers findings that the impact of networks have some influence on decisions related to migration. Secondary analysis of interviews and expert interviews clarified that specialised research clusters are strongly attractive to Russian academics older than 30 years. In particular, this applied to those who specialised in similar or connected research. Stichweh's ${ }^{5}$ finding that globalisation changes the options available to academics seems to comply with this finding. According to him, cooperation increasingly takes place between persons - and not between institutions (like companies or universities) - and thus forms networks: firstly, personal networks which exist within contexts of specialisation, and secondly, structures of networks within scientific communities which substitute organisations and automatically evolve to be global. 55 Stichweh argues: "In sciences everything depends on global networks which ensure mutual participation and the publication of findings, that thus become known to scientific communities." 56 Supporting these ideas, Han ${ }^{57}$ concludes that new and affordable technical opportunities (of information, communication, transport) intensify and foster transnational exchange among social networks.

This survey demonstrated that the decision about which networks to establish and care for depended on age and qualification of a migrant. Whereas older academics with higher formal qualifications preferred to focus on professional networks, younger ones were more interested in developing their social and personal networks. Yet, the findings did not support the general assumption by Portes and Ruben 58 that the impact of networks on the decision to migrate is so strong that it outweighs other factors. Yet findings do certainly not support the (general) assumption of Portes/ Ruben, that the impact of networks on the decision to migrate is that strong, that it pushes further factors aside. It may be, but, that within other circumstances of migration, social

\footnotetext{
52 A. Portes and G. R. Ruben, Immigrant America: A Portrait, University of California Press, Berkley and Los Angeles California, 1990.

53 C. Wegmann and K. Zimmermann, 'Netzwerke', in B. Schäfers (ed.), Grundbegriffe der Soziologie, $5^{\text {th }}$ edition pp. 251- 254, Opladen, Leske und Budrich, 1998, p. 251.

${ }^{54} \mathrm{R}$. Stichweh, Globalisierung von Wirtschaft und Wissenschaft, Produktion und Transfer wissenschaftlichen Wissens in zwei Funktionssystemen der modernen Gesellschaft, <http:// www.uni-

bielefeld.de/ (de)/soz/ iw/ projekte/ projekteabgeschlossen.html>, accessed on 23rd April, 2007, p. 5.

55 Ibid, p. 7.

56 Ibid, p. 15.

${ }^{57}$ P. Han, op. cit., p. 77.

58 A. Portes and G. R. Ruben, op. cit. 
differences or cultural contexts their presumption applies, while just the general conclusion cannot be transformed from Latin America to Russia.

\section{d. The Habitus-Conception of Bourdieu}

A number of attributes indicate that young Russian academics, as a result of their socialisation (through family, teachers, friends, etc.), value social integration. This complies with their phases of personal development, as they use social networks as an orientation. It was the process of upbringing through which parents of interviewed Russian academics conveyed values, life styles, goals in life and qualification that enabled their children to secure the achieved societal status ('social capital') and thus laid the foundation for the opportunity to emigrate. In fact, the decision to emigrate consolidates the societal status further, according to Bourdieu, as it tightens group memberships (e.g. to the "Global Scientific Community") and dissociation to other social groups (e.g. non-academics).

Evidences of a tendency of individualization, as Beck ${ }^{59}$ generally conjectures for modern societies, cannot be found among Russian academics. ${ }^{60}$ It rather seems as if the impact of globalization on personal identities is such that global and local affiliations are unifying, as Friedrichs ${ }^{61}$ assumes. For it is obvious that there is a close family bond in Russia that results in an aspiration of young Russian academics to meet the role expectations forwarded to them. This aspect in particular is, according to Nave-Herz, ${ }^{62}$ a culture bound function of families, which demonstrates the ".. key function (of a family) within the process of socialisation..."63 - a factor strongly influenced by the "..social situation and anchorage of a family in its social and physical surroundings ..."64 The effect is, as this study detects, that social situations of parents and their qualification decide upon "...variety and appropriateness of impetus for development and stiles of upbringing, which parents deliver to their children... The more comfortable the economical situation of a family, the better the formal qualification of father and mother, the more comprehensive will be the process of socialisation within the family".65 Because of this, concludes Hurrelmann, additional social impulses are delivered from the social surrounding of more privileged families.

Those processes of socialisation result in comparatively strong consistency of social status between parents and their children. Finally, it is the parents who through upbringing communicate certain interests, values, ambitions or intelligence to their children. By determining those factors, parents take a key role in performance-related positioning their children within society. This in turn is, among other factors, a precondition to decide upon social advancement or descent.

\footnotetext{
59 U. Beck, op. cit.

60 A. Siegert, 'Transmigration und Individualisierung - eine Studie über russische Akademiker', in Ch. Fischer and A. Athemeliotis (ed.) J ugend - Migration - Sozialisation - Bildung, Münster. LIT-Verlag, Band 9, 2009, p. 202.

${ }^{61} \mathrm{~J}$. Friedrichs, 'Globalisierung', in G. Endruweit and G. Trommsdorff (ed.), Wörterbuch der Soziologie, $2^{\text {nd }}$ edition, Stuttgart, Lucius und Lucius, 2002, pp. 202- 203 (p. 203).

62 R. Nave-Herz, 'Familiensoziologie', in G. Endruweit and G. Trommsdorff (ed.), Wörterbuch der Soziologie, $2^{\text {nd }}$ edition, Stuttgart: Lucius und Lucius, 2002, pp. 148- 152 (p. 149).

${ }^{63}$ K. Hurrelmann, 'Sozialisation', in G. Endruweit and G. Trommsdorff (ed.), Wörterbuch der Soziologie, , $2^{\text {nd }}$ edition, Stuttgart, Lucius und Lucius, 2002, p. 506.

64 Ibid.

65 Ibid., p. 507.
} 
With his Habitus-Conception, Bourdieu66 offers an explanation for the results of this survey. He explains differences in self-assignments of groups as a result of divergences in capital settings. It is those capital settings that offer a variety of options for action in certain situations. Societal and social surroundings define this habitus that influences action and perception. According to Bourdieu, 67 social capital is a decisive factor in gaining societal power and hence is bound to habitus which helps individuals to selfassure and dissociate towards others. ${ }^{68}$ Habitus functions in such a way because it is inseparably from a person's social position and proves to be a generative principle to reproduce social classes of society.

Reproduction of social classes, as supposed by Bourdieu, is within the context of this study supported by various findings, e.g. studies abroad. J ahr et al., 69, too, confirm the relationship between the international mobility of students and their future professional career abroad, as well as their readiness to professional mobility and qualification of parents and/ or spouse. Beyond this, Jahr et al. ${ }^{70}$ found that geographically mobile interviewees estimate their language competencies, computer literacy, abilities to solve problems, work analytically and under stress, as well as their creativity to be much higher then those who are not mobile. This shows that mobile interviewees gained selfconfidence.

Language competencies in particular foster decisions to migrate and are thus social capital in Bourdieus' sense. As Treibel points out “...speaking a common language is more the just cortically accommodation, but an important instrument to change group membership or reference group." 71 The findings implicate, that foreign languages are a kind of uniting socio-demographic attribute for being a member of the "Global Scientific Community". This would also comply with the finding of Hannerz that,

... the flow of information on a global level ... takes place on various technical and institutional levels. On all levels, but, intellectuals are those who, across borders know most about each other, who are well connected and feel that they are allies. ${ }^{72}$

Apparently, interviewees in this study shared the opinion that education confers basic competencies to cope with life ${ }^{73}$ - and knowing a foreign language is just one essential core competency. This survey regarding migration patterns of young Russian academics also indicated in various aspects that the Habitus-Conception of Bourdieu delivers

66 P. Bourdieu, Die feinen Unterschiede, Frankfurt-am-Main, Suhrkamp Taschenbuch Wissenschaft, 1987.

67 Ibid., p. 52.

68 Ibid,, p. 279.

69 V. J ahr, H. Schomburg and U. Teichler, 'Mobilität von Hochschulabsolventinnen und - absolventen in Europa', in

J . Bellmann and L. Velling (ed.), Arbeitsmärkte für Hochqualifizierte. Institut für Arbeitsmarkt- und

Berufsforschung der Bundesanstalt für Arbeits, No. 256, Nürnberg, J enior Verlag, 2002, p. 334.

70 Ibid, p. 337.

71 A. Treibel, op. cit., p. 142

72 U. Hannerz, 'Kosmopoliten und Sesshafte in der Weltkultur', in P.-U. Merz-Benz and G. Wagner (ed.), Der Fremde als sozialer Typus, Stuttgart, UTB, 2002, p. 150.

${ }^{73}$ B. Krais, 'Perspektiven und Fragestellungen der Soziologie der Bildung und Erziehung', in B. Orth (ed.), Soziologische Forschung: Stand und Perspektiven, Opladen, Leske und Budrich, 2003, p. 89. 
plausible explanations. Data and interviews clearly show connections between socialisation and personalities as well as group memberships and self-assignments. ${ }^{74}$

\section{e. Hoffmann-Nowotny's theory on social layers}

Globalisation has a great impact on worldwide labour markets for the highly qualified, their networking, self-assignment and an increasing geographical mobility. Which impetus, however, was important to young Russian academics, motivating them to migrate? And what criteria did they use to decide where to migrate?

One approach to explain migration is forwarded by Hoffmann-Nowotny and his theory of social layers. ${ }^{75}$ According to him, a person who can carry into effect the claim of central social values has power. A person whose claim is considered to be legitimate has prestige. Prestige is the basis for power and thus carries the function of legitimating. ${ }^{76}$ Status expresses the degree to which central social values could be obtained. A problem in many societies is that their members have the prestige to legitimately claim certain values (income, education etc.), but do not have the power to put their claim into practice.

Comparing societies shows different degrees of conflicts: Migrants leave societies with intense conflicts and decide on societies which contain conflicts on lower scale. They do so, because migration is to be seen as a result of a "situation of social comparison" 77 . By protagonists leaving societies where they cannot accomplish their demands on social advancement and/ or higher income, frictions in their home country reduce. HoffmannNowotny considers such gaps between power and prestige as structural conflict which, if a certain limit is exceeded or if the causes of structural conflicts are repressed, those conflicts become anomic ${ }^{78}$. Anomie leads to feelings of helplessness and perplexity and individuals as well as societies tend to balance those conflicts.

\section{Conclusion}

Twenty years after the fall of the Iron Curtain, the migration patterns of young Russian academics, socialised and educated in Russia with open borders, are examined. Representative internet-based surveys showed that many interviewees have parents with academic qualification and started learning foreign languages early. Although their societal positioning is not yet completed, they possess numerous socio-demographic attributes (academic qualification, foreign language competencies) and aims in life (e.g. values, career orientation, cosmopolitanism), which are communicated through socialisation, that determine their future social position.

\footnotetext{
74 A. Siegert, Gründe hochqualifizierter russischer Transmigranten, nach Deutschland zu emigrieren. Eine empirische Studie unter russischen Akademikern, Aachen, Shaker Verlag, 2008.

75 H.-J . Hoffmann-Nowotny, 'Migrationssoziologie', in H. Kerber (ed.), Spezielle Soziologien Rowohlts Enzyklopädie, Vol. 542, Hamburg, Rohwolt Verlag, 1994, pp. 388- 406.

76 H.-J . Hoffmann-Nowotny, Soziologie des Fremdarbeiterproblems, Stuttgart,,Enke Verlag, 1973, p. 29.

77 S. Ronzani, Arbeitskräftewanderung und gesellschaftliche Entwicklung. Erfahrungen in Italien, in der Schweiz und in der Bundesrepublik Deutschland, Schriften des Wissenschaftszentrums Berlin, Vol. 15, Königstein i.Ts., 1980, p. 51.

78 Ibid., p. 21.
} 
There is evidence that this population feels close relationships to their social roots (family, relatives and friends) and life' values taught by their parents. This applies although, compared to other age groups of the population, youth does not pay much attention to geographical distance of immigration countries to their home land. More than other age groups, youth is interested in setting up contacts with Russian Diaspora communities abroad. In this regard, they differ from older Russian academics who rather seek contact with "global scientific communities". Evidently self-assignments play a great role in worldwide networking.

The readiness of young Russian academics ( $<25$ years) to migrate is no more distinctive than that of the comparison group. Yet, there are great divergences regarding reasons to immigrate to Germany. Young Russian academics appreciate that they do not need to pay university fees, and they are encouraged by positive opinions on Germany within their social surroundings. They furthermore value the rule of law, freedom/liberty and democracy. The prospect for higher income and the opportunity to travel from Germany around the world are additional reasons youth cite for emigrating that are different from those of older interviewees. Social contacts are more important to young Russians who have already immigrated than getting in touch with scientific communities of the country of destination. Finally, it is their living situation that defines the importance of respective reasons to migrate.

Several empirical results indicate that the migration of young Russian academics can plausibly be explained through Bordieu's Habitus-Conception. As far as it comes to concrete migration decisions, the theories of Bourdieu and Hoffmann-Nowotny complement each other. While Bourdieu explains how education and the conveyance of values ensure achieved social status across generations, Hoffmann-Nowotny delivers an assertion as to why highly qualified Russian academics may migrate. Thus, he makes transparent what happens when prospects cannot (or not to the aspired extend) be realised in the society of origin. Hoffmann-Nowothny's theory of social layers proves to be plausible at least in the specific context of migration between Russia and Germany.

It remains to be seen if, or to what extend, these findings about migration between Russia and Germany may be relevant to other (cultural, social, economic etc.) contexts. This will require additional research. 